\title{
EVALUASI KINERJA GURU MELAKSANAKAN PEMBELAJARAN DARING MELALUI SUPERVISI KEPALA SEKOLAH
}

\section{EVALUATION OF TEACHER PERFORMANCE TO CONDUCT ONLINE LEARNING THROUGH PRINCIPAL SUPERVISION}

\author{
Wahidah' \\ Bulkani2

\section{IGuru SMPN-6} \\ Palangka Raya, \\ Indonesia, Indonesia \\ 2Universitas \\ Muhammadiyah \\ Palangka Raya, \\ Indonesia
}

\begin{abstract}
Abstrak
Tujuan penelitian ini adalah untuk mengetahui (I). Reliabilitas instrumen supervisi daring yang digunakan kepala sekolah untuk mengukur kinerja guru (2). Kinerja guru dalam melaksanakan pembelajaran daring, (3). Korelasi usia dan masa kerja dengan kinerja guru dalam pembelajaran daring (4). Perbedaan kinerja guru dalam pembelajaran daring jika ditinjau dari jenis kelamin, pangkatgolongan, dan jenjang pendidikan.

Penelitian menggunakan metode korelasional dan komparatif, dengan sampel sebanyak 47 orang guru SMPN-6 Palangka Raya. Teknik pengumpulan data menggunakan observasi luring dan daring. Teknik analisis data menggunakan analisis korelasi, uji-t, dan analisis variansi satu jalur. Dari hasil penelitian disimpulkan (I). Instrumen supervisi daring yang digunakan kepala sekolah merupakan instrumen yang reliabel karena hasil pengukurannya berkorelasi positif dan signifikans sebesar $0,7 \mathrm{I}$ dengan hasil supervisi luring sebelum pandemi. (2). Kinerja guru dalam melaksanakan pembelajaran daring berada pada kategori baik dan sangat baik, (3). Usia dan masa kerja guru tidak berkorelasi dengan kinerja guru dalam pembelajaran daring. (4). Jenjang pendidikan dan pangkat guru, merupakan faktor yang menyebabkan perbedaan kinerja guru dalam pembelajaran daring, sedangkan faktor jenis kelamin, bukan merupakan faktor yang menyebabkan perbedaan kinerja guru. Implikasi penelitian ini adalah perlunya perumusan kebijakan pembinaan guru berdasarkan pangkat dan jenjang pendidikan, sehingga kinerja guru dalam pembelajaran daring dapat ditingkatkan.
\end{abstract}

\section{Kata Kunci: \\ Supervisi Daring Kepala \\ Sekolah, Kinerja guru}

\section{Keywords:}

The Principal's online supervision, teacher performance

Abstract

The purpose of this study is to determine (I). The reliability of online supervision instruments used by principals to measure teacher performance (2). Teacher performance in implementing online learning, (3). Correlation of age and long of service with teacher performance in online learning (4). Differences of teacher performance in online learning when viewed from gender, level of employee, and level of education.

The research used correlational and comparative methods, with a sample of 47 teachers at SMPN-6 Palangka Raya. Data collection techniques using offline and online observations. Data analysis techniques used correlation analysis, t-test, and one-way analysis of variance. From the research results concluded (I). The online supervision instrument used by the principal is a reliable instrument, because the measurement results have a positive correlation and a significance of 0.71 with the results of offline supervision before the pandemic era. (2). The teacher's performance in implementing online learning is in the good and very good categories, (3). Age and long of service of teachers, do not correlate with teacher performance in online learning. (4). Level of employee and level of education are factors that cause differences in teacher performance in online learning, while the age are not. The implication of this research is the need to formulate teacher guidance policies based on level of employee and level of education, so that teacher performance in online learning can be improved.

Accepted

Maret 2021

Published

April 2021
\end{abstract}

(C) 2021 The Authors. Published by Institute for Research and Community Services Universitas Muhammadiyah Palangkaraya. This is Open Access article under the CC-BY-SA License (http://creativecommons.org/licenses/by-sa/4.0/).

\section{PENDAHULUAN}

Kejadian pandemi Covid-19 yang melanda Indonesia sejak bulan Maret 2020, telah merubah banyak aspek kehidupan, termasuk dalam bidang pendidikan. Keadaan pandemi memaksa sistem pendidikan di Indonesia untuk melakukan berbagai penyesuaian. Diantara perubahan tersebut adalah berubahnya teknik pembelajaran yang semula tatap muka menjadi pembelajaran daring. Konsekuensi dari perubahan teknik pembelajaran tersebut adalah berubahnya sistem evaluasi keberhasilan pembelajaran yang dilakukan oleh kepala sekolah, yakni melalui supervisi kepala sekolah. Kepala sekolah dituntut untuk memiliki kemampuan mengevaluasi kinerja guru dalam melaksanakan 
pembelajaran daring. Dalam keadaan pandemi, evaluasi tersebut juga harus dilakukan secara daring kepala sekolah. Sebagai proses evaluasi, supervisi kepala sekolah terhadap kinerja guru dalam melaksanakan pembelajaran daring bertujuan untuk menilai kinerja dan ketercapaian proses pembelajaran yang dilaksanakan guru. Pada dasarnya, evaluasi tersebut bermuara pada tujuan untuk memberi umpan balik dan perbaikan proses pembelajaran (Kepmendikbud Nomor 7/9/P/2020). Dalam konteks ini, evaluasi oleh kepala sekolah melalui supervisi, bukan hanya berfungsi untuk menilai kinerja guru, tapi juga berfungsi untuk mendorong kemajuan proses pembelajaran yang berimplikasi pada ketercapaian hasil belajar peserta didik. Hal ini sesuai dengan salah satu fungsi evaluasi pembelajaran, yakni sebagai cara untuk mendorong peningkatan hasil belajar peserta didik (Sax, 1980). Evaluasi bahkan bisa berfungsi sebagai sarana pendorong peningkatan berbagai aspek kehidupan, termasuk aspek-aspek hasil pembelajaran (Stufflebeam, 2007).

Supervisi kepala sekolah terhadap pelaksanaan pembelajaran daring yang dilaksanakan guru, merupakan salah satu kewajiban yang harus dilakukan. Dalam Pedoman Penyelenggaraan Belajar dari Rumah dalam Masa Darurat Penyebaran Covid19 (Surat Edaran Kemdikbud, 2020) disebutkan bahwa salah satu tugas kepala sekokah adalah melakukan pembinaan dan pemantauan terhadap guru dalam melaksanakan pembelajaran daring, serta memastikan guru merencanakan serta melaksanakan pembelajaran daring yang bermakna. Sementara Lembaga Pengembangan dan Pemberdayaan Kepala Sekolah dan Pengawas Sekolah (LPPKSPS, 2020) Kementerian Pendidikan dan Kebudayaan, menyatakan bahwa salah satu tugas pokok kepala sekolah pada saat pandemi adalah membuat perencanaan dan melaksanakan supervisi terhadap kinerja guru dalam melaksanakan pembelajaran daring, yang meliputi pra observasi, pada saat pembelajaran, dan pasca pembelajaran, serta melakukan evaluasi terhadap hasil supervisi.

Supervisi kepala sekolah memiliki manfaat besar bagi perbaikan dan peningkatan kualitas pembelajaran serta kinerja guru. Sonedi, Sholehah, \& Dihasbi (2018), menemukan bahwa kepala sekolah sebagai supervisor berperan dalam meningkatkan kinerja guru. Adanya supervisi oleh kepala sekolah membantu meningkatkan kinerja guru sehingga pembelajaran lebih berkualitas (Supardi, 2017), dan meningkatkan impelemtasi tugas-tugas pokok guru (Wandi, 2018). Faktor yang berhubungan dengan kinerja guru antara lain pola kepemimpinan kepala sekolah (Sonedi, 2016), dan pelaksanaan supervisi akademik oleh kepala sekolah (Hasanah, 2019, Niswah, 2020).

Ada beberapa cara yang dapat digunakan kepala sekolah untuk melakukan supervisi, antara lain melalui observasi dan wawancara. Akan tetapi dalam keadaan pandemi, observasi secara langsung kurang memungkinkan untuk dilaksanakan, sehingga dilakukan evaluasi supervisi secara daring. Supervisi daring dilakukan dengan cara melakukan observasi terhadap proses pembelajaran daring menggunakan pedoman observasi yang telah disesuaikan. Penyesuaian itu terutama dilakukan pada item-item observasi tentang penggunaan teknologi informasi oleh guru. Penyesuaian juga dilakukan terhadap teknik observasi, yakni dengan menggunakan berbagai media daring seperti WhatsApp atau google form. Observasi yang dilakukan melalui media sosial termasuk teknik yang disarankan oleh Kemendikbud RI untuk digunakan sebagai teknik supervisi kepala sekolah di masa pandemi (LKKSPS, 2020).

Penggunaan observasi daring memiliki kelebihan dan kekurangan. Diantara kelebihan penggunaan teknik observasi daring adalah kemudahan kepala sekolah untuk melaksanakannya karena observasi cukup dilakukan dari tempat berbeda. Kepala sekolah tidak harus bergabung secara fisik ke dalam kelas, sehingga membantu menerapkan protokol kesehatan di saat pandemi. Namun demikian, secara teknis terdapat beberapa hambatan yang mendasar, misalnya ketergantungan kepala sekolah terhadap ketersediaan kouta dan jaringan internet yang stabil, serta menuntut kemampuan penggunaan teknologi informasi. Selama ini, kendala yang dihadapi para pendidik dalam melaksanakan pembelajaran daring adalah ketersediaan jaingan yang stabil (Rahmawaty, 2020), sementara kemampuan guru dalam penggunaan berbagai perangkat digital dan aplikasi daring masih rendah (Sekretariat Komisi X DPR-RI, 2020). Secara konseptual, kelemahan evaluasi model daring dan berbasis pengamatan serta protofolio adalah adanya keraguan terhadap tingkat akurasi dan reliabilitas 
hasil pengukurannya (Bulkani, 2020, Widoyoko, 20II). Situasi dan kondisi yang dihadapi oleh responden yang diukur juga merupakan faktor yang mempengaruhi reliabilitas hasil evaluasi yang diperoleh (Mardapi, 20I2). Faktor lain yang menyebabkan kelemahan adalah kurangnya pengawasan pada saat guru melaksanakan pembelajaran, karena terbatasnya layar perangkat yang digunakan.

Meskipun demikian, reliabilitas hasil evaluasi dapat ditingkatkan, antara lain dengan cara melihat konsistensi hasil suatu evaluasi dengan evaluasi sebelumnya. Melakukan supervisi beberapa kali adalah salah satu cara untuk mengejar tingkat reliabilitas hasil supervisi. Dengan melihat konsistensi hasil dari beberapa kali supervisi, kepala sekolah dapat memperoleh gambaran lebih lengkap tentang kinerja guru. Hasil suatu supervisi dianggap reliabel jika hasil tersebut memiliki korelasi positif yang kuat dengan hasil supervisi sejenis yang dilaksanakan sebelumnya. Reliabilitas semacam ini juga disebut sebagai stabilitas (Mardapi, 20I2), atau reliabilitas eksternal (Widoyoko, 20II), atau reliabilitas kriterium (Sax, 1980). Artinya, hasil supervisi yang dilakukan secara daring tersebut dianggap cukup reliabel dan dapat dipercaya hasilnya, jika hasil tersebut berkorelasi positif dan kuat dengan hasil supervisi sejenis yang dijadikan kriterium. Dalam hal ini, hasil supervisi yang dijadikan kriterium adalah hasil supervisi yang dilakukan secara luring sebelum masa pandemi.

Pada dasarnya, supervisi kepala sekolah terhadap kinerja guru dalam melaksanakan pembelajaran daring ditujukan untuk memastikan efektivitas proses pembelajaran daring. Penggunaan teknologi informasi dapat membantu supervisor dalam melaksanakan supervisi secara real time tanpa dibatasi oleh ruang dan waktu (Rugaiyah, 2016). Supervisi tersebut bukan hanya bermanfaat bagi guru dan kepala sekolah, tetapi akan berguna untuk memastikan bahwa peserta didik telah mencapai tujuan pembelajarannya meskipun belajar dari rumah. Supervisi tersebut meliputi 3 tahap, yakni praobservasi, tahap observasi, dan post-observasi (LPPKSPS, 2020). Dalam tahap pra-observasi, kepala sekolah bertugas melakukan pertemuan awal dengan para guru untuk merancang dan merencanakan sistem pembelajaran daring, termasuk melakukan pengecekan dan menilai dokumen rencana pembelajaran guru. Dalam tahap pelaksanaan observasi, kepala sekolah melakukan pemantauan pelaksanaan pembelajaran daring dengan beberapa cara, antara lain memantau secara langsung melalui aplikasi Zoom, WhatsApp, Google Classroom, dan semacamnya. Sedangkan dalam tahap post-observasi, kepala sekolah dituntut untuk dapat menganalisis hasil observasi dan memberikan feed-back serta melaksanakan tindak lanjut untuk perbaikan kinerja guru.

Dilihat dari substansi materi yang diobservasi, supervisi daring oleh kepala sekolah terhadap kinerja guru dalam pembelajaran daring, mencakup banyak kemampuan dan kompetensi guru. Kompetensi utama yang dibutuhkan guru dalam melaksanakan pembelajaran daring adalah penguasaan teknologi informasi. Dalam tahap perencanaan, guru harus mampu melakukan persiapan perangkat pembelajaran seperti memiliki dokumen Rencana Pelaksanaan Pembelajaran (RPP). Guru juga harus mampu merencanakan konsep pembelajaran daring yang akan dilaksanakan, misalnya apakah daring murni ataukah model blended-learning. Guru juga harus mengidentifikasi sarana belajar yang dibutuhkan, jenis aplikasi yang akan digunakan, serta bahan ajar daring yang disiapkan. Selain komponen penguasaan teknologi informasi, guru juga dituntut untuk mampu mengelola dan mengkondisikan pembelajaran kelas daring, sebagaimana juga pada pengelolaan kelas secara luring.

Dilihat dari banyaknya komponen kompetensi yang harus dimiliki, terutama penguasaan teknologi informasi, maka terdapat banyak faktor yang dapat mempengaruhi kemampuan guru. Salah satu faktor adalah usia guru. Beberapa temuan menyimpulkan bahwa guru-guru yang lebih muda, relative lebih familiar dengan penggunaan teknologi informasi dibandingkan dengan guru-guru yang usianya lebih tua. Hal ini terkait dengan fenomena bahwa 78\% pengguna internet di Indonesia adalah kaum muda pada rentang usia 25-34 tahun, sementara pengguna dari kalangan usia di atas 55 tahun hanya 2\% (Ashari, 2018). Sedangkan Efendi et.al (2019) menemukan bahwa faktor umur secara simultan berpengaruh terhadap kompetensi guru bersama dengan faktor lain. 
Beberapa faktor lain yang diduga berpengaruh terhadap kompetensi guru adalah faktor jenis kelamin, masa kerja, dan jenjang pendidikan. Efendi et.al (2019) menemukan bahwa faktor-faktor tersebut di atas secara bersama dan simultan berpengaruh terhadap kompetensi guru. Khatoon et.al (20II), menemukan bahwa guru-guru perempuan yang mengajar di SMP Pakistan cenderung lebih disukai karena dianggap lebih kompeten dan mampu lebih banyak meluangkan waktunya untuk melaksanakan pembelajaran. sedangkan Marjoon \& Nugroho (2019), menemukan bahwa guru dengan tingkat pendidikan jenjang S2 memiliki skor kompetensi paling tinggi dibandingkan dengan guru berpendidikan lebih rendah.

Dari beberapa uraian di atas, dapat dirumuskan pertanyaan penelitian sebagai berikut (I). Apakah penggunaan instrumen supervisi secara daring reliabel atau bisa dipercaya untuk mengukur kinerja guru dalam pembelajaran daring ? (2). Bagaimana kinerja guru dalam pembelajaran daring ? (3). Apakah usia berkorelasi dengan kinerja guru dalam pembelajaran daring ? (4). Apakah masa kerja berkorelasi dengan kinerja guru dalam pembelajaran daring ? (4). Apakah ada perbedaan kinerja guru dalam pembelajaran daring jika ditinjau dari jenis kelamin, masa kerja, pangkat-golongan, dan jenjang pendidikan?

\section{METODE}

Penelitian ini menggunakan pendekatan kuantitatif, dengan metode korelasional dan komparatif. Penelitian dilaksanakan pada bulan Januari 202I dengan data pembanding yang dikumpulkan pada masa sebelum pandemi yakni bulan Januari 2020. Populasi penelitian adalah guru SMPN-6 Palangka Raya. Sampel penelitian adalah seluruh guru SMP Negeri-6 Palangka Raya sebanyak 47 orang.

Variabel penelitian adalah kinerja guru dalam pembelajaran daring sebagai variabel terikat. Sedangkan variabel bebasnya adalah usia, masa kerja, jenis kelamin, dan pangkat-golongan guru. Variabel jenis kelamin guru dibedakan menjadi guru laki-laki dan perempuan. Sedangkan variabel pangkat golongan guru dibedakan menjadi 6 kategori, yakni pangkat III-a hingga IV-b. Variabel kinerja guru dalam pembelajaran daring diukur menggunakan instrumen supervisi daring kepala sekolah, sedangkan variabel usia, masa kerja, jenis kelamin, dan pangkat-golongan guru dikumpulkan dengan teknik dokumentasi. Instrumen supervisi daring yang dilakukan kepala sekolah, terdiri dari 4 komponen yang melambangkan tahapan proses pembelajaran daring yang dilaksanakan guru, yakni aspek telaah terhadap rencana pelaksanaan pembelajaran (RPP) dengan 9 item observasi, aspek pra-observasi dengan 6 item observasi, aspek pelaksanaan pembelajaran dengan 40 item observasi, dan aspek pasca observasi dengan 16 item observasi. Total keseluruhan item yang diobservasi adalah 7I item. Pensksoran dilakukan dengan memperhatikan bobot dari masing-masing aspek. Aspek telaah RPP memiliki bobot 15\%, aspek pra-observasi memiliki bobot 10\%, aspek observasi berbobot $60 \%$, dan aspek pasca observasi berbobot $15 \%$.

Prosedur penelitian meliputi 3 tahapan, yakni tahapan dokumentasi, tahapan observasi, dan tahapan analisis data. Tahapan dokumentasi dimaksudkan untuk mengumpulkan data hasil pengukuran kinerja guru dalam pembelajaran luring pada tahun 2020, dan data variabel-variabel bebas berupa data usia, masa kerja, jenis kelamin, jenjang pendidikan, dan pangkat golongan guru. Pada tahapan observasi, kepala sekolah melakukan observasi secara daring pada saat guru melakukan pembelajaran daring, menggunakan instrumen supervisi yang telah disusun. Setelah itu, pada tahap ketiga dilakukan analisis data hasil penelitian sesuai dengan tujuan penelitian.

Analisis data penelitian menggunakan statistika deskriptif dan statistika inferensial. Untuk mengetahui reliabilitas instrumen supervisi daring yang digunakan, dilakukan pengujian korelasi antara hasil pengukuran kinerja guru menggunakan instrumen daring dengan hasil pengukuran kinerja guru pada tahun 2020 yang dilakukan secara luring sebelum pandemi terjadi. Kedua pengukuran kinerja guru ini dilakukan oleh kepala sekolah menggunakan instrumen berbeda tetapi prinsipnya unidimensi, yakni secara substantif mengukur hal yang sama. Koefisien korelasi antara dua hasil pengukuran ini melambangkan tingkat reliabilitas eksternal dan stabilitas hasil pengukuran. Koefisien reliabilitas dianggap sudah cukup memadai jika diperoleh angka di atas 0,70. Kategorisasi skor kinerja guru didasarkan tabel kriteria berikut: 
Tabel I: Kategorisasi Kinerja Guru dalam Pembelajaran Daring

\begin{tabular}{ll}
\hline Rentang skor & Kategori \\
\hline $90<$ Skor $\leq 100$ & Sangat baik \\
$80<$ Skor $\leq 90$ & Baik \\
$70<$ Skor $\leq 80$ & Cukup \\
$60<$ Skor $\leq 70$ & Kurang \\
$0<$ Skor $\leq 60$ & Sangat kurang \\
\hline
\end{tabular}

Untuk menguji korelasi antar variabel penelitian, digunakan analisis korelasi product moment. Sedangkan untuk menguji perbedaan antar kelompok menggunakan uji-t dan analisis variansi. Semua pengujian statistik menggunakan taraf signifikansi 5\% dengan bantuan software SPSS versi 20.

\section{HASIL DAN PEMBAHASAN}

\section{Hasil Penelitian}

\section{Reliabilitas Instrumen Supervisi Daring}

Dalam penelitian ini, reliabilitas instrumen supervisi daring diukur melalui tingkat konsistensi atau stabilitas hasil pengukuran instrumen tersebut. Konsistensi hasil pengukuran dapat dilihat dari koefisien korelasi antara skor hasil pengukuran menggunakan suatu instrumen, dengan skor hasil pengukuran sebelumnya yang digunakan sebagai pembanding. Dalam konteks ini, sebagai pembanding digunakan skor hasil supervisi kepala sekolah terhadap kinerja guru yang dilakukan secara luring pada saat sebelum pandemi. Asumsi dasar yang digunakan adalah, secara substantif instrumen supervisi luring dan daring yang digunakan adalah unidimensi karena mengukur hal yang sama. Beberapa penyesuaian hanya dilakukan agar penggunaan instrumen supervisi memungkinkan secara daring.

Dari hasil penelitian diperoleh koefisien korelasi antara skor kinerja guru menggunakan instrumen supervisi luring dan supervisi daring, sebagaimana tabel berikut :

Tabel 2: Koefisien Korelasi antara Skor Supervisi Luring dan Daring

\begin{tabular}{llrr}
\hline & & Kinerja Luring & \multicolumn{2}{c}{ Kinerja Daring } \\
\hline Kinerja Luring & Coefficient & 1,00 & $0,71 \mathrm{I}$ \\
& Sig. (2-tailed) & & 0,000 \\
Kinerja Daring & Coefficient & $0.71 \mathrm{I}$ & \\
& Sig. (2-tailed) & 0,000 & \\
& & Skor & kinja
\end{tabular}

Dari tabel di atas diperoleh koefisien korelasi sebesar $r_{(46 ; 0,05)}=0.7 \mathrm{II}$, dengan taraf signifikansi 0,00 . Ini berarti bahwa pada signifikansi 5\%, koefisien korelasi tersebut sangat signifikans. Dengan demikian dapat disimpulkan terdapat korelasi yang kuat antara skor kinerja guru yang diukur secara luring sebelum pandemi, dengan skor kinerja guru dalam melaksanakan pembelajaran daring pada masa pandemi. Korelasi yang kuat tersebut juga melambangkan adanya konsistensi hasil pengukuran kinerja guru menggunakan dua jenis instrumen yang berbeda tetapi unidimensi. Koefisien korelasi antara skor hasil pengukuran oleh dua jenis instrumen, baik yang setara maupun instrumen yang sama digunakan berulang, adalah melambangkan koefisien reliabilitas instrumen tersebut.

\section{Deskripsi kinerja guru melaksanakan pembelajaran daring}


Berdasarkan tabel kategorisasi, maka sebaran skor kinerja guru dalam melaksanakan pembelajaran daring, dapat dilihat pada diagram berikut:

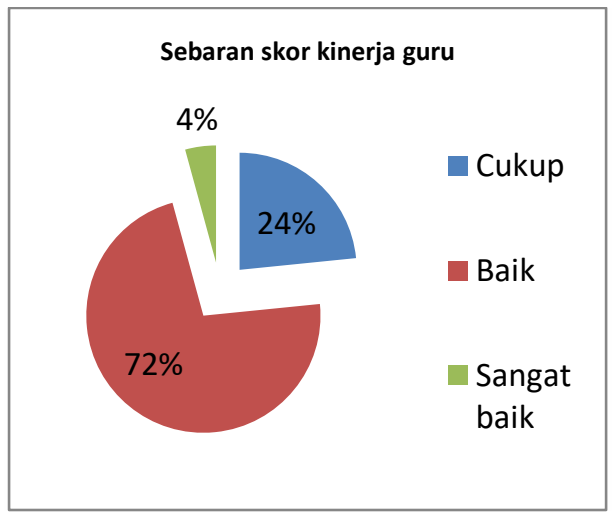

Dari gambar di atas tampak bahwa $72 \%$ guru memperoleh skor kinerja baik, $4 \%$ memperoleh kinerja sangat baik, dan $24 \%$ guru memperoleh skor kinerja cukup. Tidak ada guru yang memperoleh skor kinerja dengan kategori kurang atau sangat kurang..

Secara deskriptif, skor kinerja guru dalam melaksanakan pembelajaran daring cenderung tinggi pada aspek telaah RPP, dan aspek pelaksanaan pembelajaran yang diobservasi. Berdasarkan instrumen supervisi kepala sekolah secara daring, kinerja menyusun RPP dan kinerja melaksanakan pembelajaran daring, merupakan kompetensi yang selama ini telah dimiliki guru. Kemampuan yang dibutuhkan guru dalam menyusun RPP pembelajaran daring relatif tidak jauh berbeda dengan yang dibutuhkan dalam pembelajaran luring. Hal yang sama juga terjadi pada kemampuan melaksanakan pembelajaran. Tahapan-tahapan pembelajaran daring yang diobservasi, seperti tahap membuka, melaksanakan, dan menutup pembelajaran, relatif tidak berbeda dengan tahapan pembelajaran luring yang telah biasa dilakukan guru pada masa sebelum pandemi.

Sebaliknya, skor kinerja guru cenderung rendah pada tahapan pra-observasi. Tahapan ini memuat kemampuan guru untuk mempersiapkan perangkat pembelajaran daring, perencanaan sarana belajarnya, aplikasi serta bahan ajar daring yang digunakan. Dengan kata lain, tahapan pra observasi merupakan tahapan kritis yang menuntut kemampuan guru dalam penguasaan teknologi informasi. Hasil telaah terhadap komponen pra-observasi, menemukan bahwa pada umumnya guru kurang mampu melakukan penyesuaian antara model dan aplikasi pembelajaran daring yang digunakan, dengan karakteristik peserta didik.

\section{Korelasi Usia dengan Kinerja Guru dalam Pembelajaran Daring}

Dari hasil penelitian terhadap 47 orang guru yang melaksanakan pembelajaran daring, diperoleh rentang usia guru antara 33-57 tahun, dengan ratarata usia guru adalah 48 tahun dan simpangan baku 7,66 tahun, serta skewness $-0,60$. Skewness negatif berarti bahwa distribusi usia guru yang diteliti lebih banyak berada pada sisi kanan kurva, yang mengindikasikan bahwa sebagian besar guru yang diteliti adalah guru dengan usia di atas rata-rata.

Selengkapnya sebaran data usia guru digambarkan pada diagram berikut : 


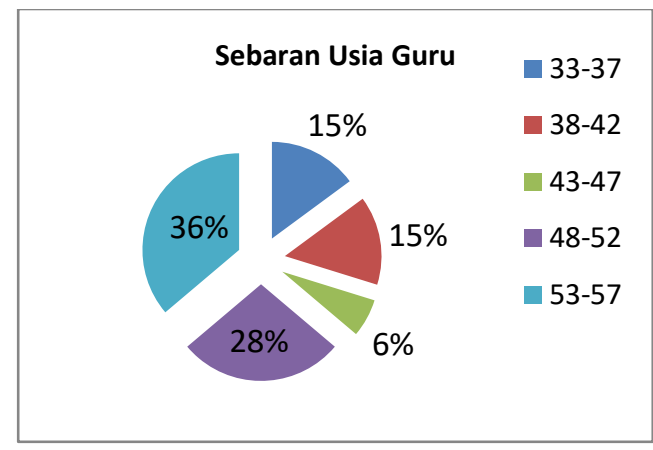

Dari diagram di atas, tampak bahwa lebih dari $60 \%$ guru yang menjadi responden adalah guru-guru senior dengan usia 50 tahun ke atas.

Dari analisis korelasi menggunakan SPSS, diperoleh tabel hasil analisis korelasi antara usia dan kinerja guru sebagai berikut :

Tabel 3: Koefisien Korelasi Usia dengan Kinerja Guru

\begin{tabular}{|c|c|c|c|}
\hline & & Usia Guru & Kinerja Daring \\
\hline Usia Guru & $\begin{array}{l}\text { Coefficient } \\
\text { Sig. (2-tailed) }\end{array}$ & 1,00 & $\begin{array}{l}0,181 \\
0,223\end{array}$ \\
\hline Kinerja Daring & $\begin{array}{l}\text { Coefficient } \\
\text { Sig. (2-tailed) }\end{array}$ & $\begin{array}{l}0.181 \\
0,223\end{array}$ & \\
\hline
\end{tabular}

\begin{abstract}
Dari tabel di atas, diperoleh koefisien korelasi usia dengan kinerja guru dalam melaksanakan pembelajaran daring, sebesar $r_{(46 ; 0,05)}=$ 0,181 , dengan nilai signifikansi pada uji dua ekor signifikansi yang digunakan dalam penelitian ini adalah $5 \%$ atau 0,05, maka disimpulkan bahwa korelasi tersebut tidak signifikans. Dengan demikian disimpulkan bahwa tidak ada korelasi usia dengan kinerja guru dalam melaksanakan pembelajaran daring.
\end{abstract}

\section{Korelasi Masa Kerja dengan Kinerja Guru dalam Pembelajaran Daring}

Dari hasil penelitian terhadap 47 orang guru yang melaksanakan pembelajaran daring, diperoleh adalah 0,223. Artinya, koefisien korelasi ini akan signifikans jika kita menggunakan taraf $23,3 \%$. Tetapi karena

taraf

rentang masa kerja guru antara 3-38 tahun, dengan rata-rata masa kerja 24 tahun dan simpangan baku 9,94 tahun, serta skewness $-0,42$. Ini mengindikasikan bahwa sebagian besar guru yang diteliti telah memiliki masa kerja yang lama dan di atas 24 tahun. Skewness 0,42 mengindikasikan bahwa distribusi masa kerja guru cenderung lebih banyak berada di atas rata-rata. $\mathrm{Hal}$ ini juga memiliki relevansi dengan usia guru yang diteliti.

Sebaran data masa kerja guru dapat dilihat dari diagram berikut:

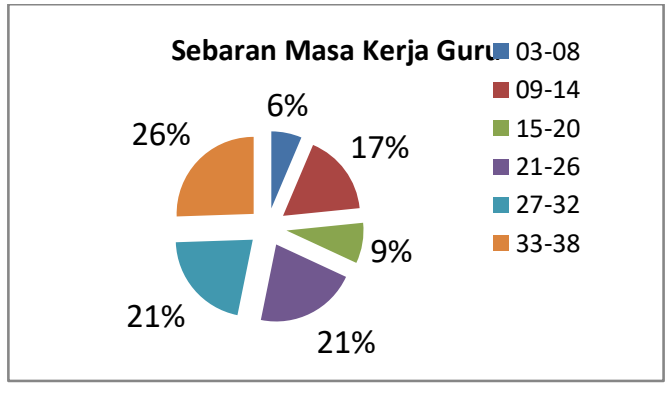

Dari hasil analisis korelasi menggunakan SPSS, diperoleh tabel analisis korelasi antara masa kerja dan kinerja guru sebagai berikut :

Tabel 4: Koefisien Korelasi Masa Kerja dengan Kinerja Guru

\begin{tabular}{llrr}
\hline & & Masa Kerja Guru & Kinerja Daring \\
\hline Masa Kerja Guru & Coefficient & 1,00 & 0,215 \\
& Sig. (2-tailed) & & 0,147 \\
\hline
\end{tabular}




\begin{tabular}{lll}
\hline Kinerja Daring & Coefficient & 0.215 \\
& Sig. (2-tailed) & 0,147 \\
\hline
\end{tabular}

Dari tabel di atas, diperoleh koefisien korelasi antara masa kerja dengan kinerja guru dalam melaksanakan pembelajaran daring sebesar $r_{(46 ; 0,05)}=0,215$, dengan nilai signifikansi adalah 0,147 . Ini berarti pada taraf signifikansi $5 \%$, disimpulkan bahwa tidak ada korelasi antara masa kerja dengan kinerja guru dalam melaksanakan pembelajaran daring.

$\mathrm{Hal}$ ini mengindikasikan bahwa guru-guru senior dan junior, relatif memiliki kinerja yang sama dalam melaksanakan pembelajaran daring. Dengan asumsi bahwa semakin lama masa kerja guru maka usianya juga semakin bertambah, maka hasil penelitian ini juga memperkuat temuan sebelumnya, bahwa usia guru tidak memiliki korelasi dengan kinerja guru.

\section{Perbedaan Kinerja Guru ditinjau dari Jenis Kelamin}

Dari hasil penelitian diketahui bahwa sebagian besar guru yang menjadi responden adalah guru perempuan, yakni sebanyak 38 orang atau $81 \%$ dari 47 orang guru SMPN-6 Palangka Raya. Hal itu tergambar pada diagram berikut:

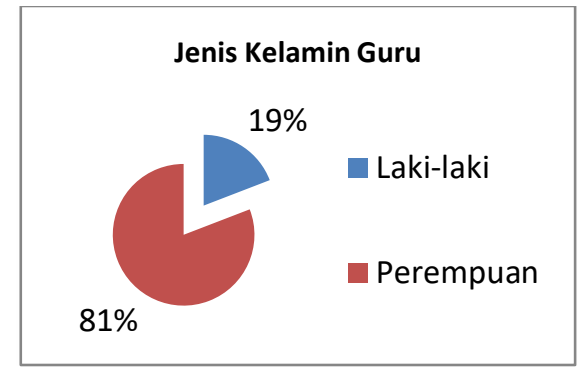

Dari hasil analisis data penelitian menggunakan SPSS, diperoleh hasil pengujian perbedaan sebagai berikut :

Tabel 5: Perbedaan Kinerja berdasarkan Jenis Kelamin

\begin{tabular}{lccccc}
\hline & $\begin{array}{l}\text { Levene's Test } \\
\text { for Equality of } \\
\text { Variances }\end{array}$ & $\begin{array}{l}\text { t-test for } \\
\text { Equality } \\
\text { of Means }\end{array}$ & & & \\
\hline F & Sig. & t & df & $\begin{array}{l}\text { Sig(2 } \\
\text { tailed })\end{array}$ \\
\hline $\begin{array}{l}\text { Equal } \\
\text { variances }\end{array}$ & 4,605 & 0,037 & $-I, 168$ & 45 & 0,240 \\
$\begin{array}{l}\text { assumed } \\
\begin{array}{l}\text { Equal } \\
\text { variances not }\end{array} \\
\text { assumed }\end{array}$ & & & & & \\
\hline
\end{tabular}

Dari tabel di atas diperoleh $t_{(45 ; 0,05)}=-0,168$ (jika diasumsikan variansi kedua kelompok adalah sama), atau $t_{(45 ; 0,05)}=-0,916$ (jika diasumsikan variansi kedua kelompok adalah berbeda). Pada taraf $5 \%$, nilai $t_{(45 ; 0,05)}$ ini tidak signifikans berlaku pada populasi. Artinya, tidak terdapat perbedaan kinerja guru dalam melaksanakan pembelajaran daring antara guru lakilaki dan guru perempuan. Secara deskriptif, rata-rata skor kinerja pembelajaran daring guru laki-laki adalah 82.21, tidak jauh berbeda dengan rata-rata skor kinerja guru perempuan sebesar 84.24. Hal ini juga bermakna bahwa perbedaan rata-rata skor kinerja pembelajaran daring tersebut hanya terjadi pada sampel, bukan pada populasi.

\section{Perbedaan Kinerja Guru ditinjau dari Jenjang Pendidikan}

Dari data penelitian diketahui bahwa sebaran tingkat pendidikan guru terdiri dari dua jenjang, yakni pendidikan sarjana (SI), dan pendidikan magister (S2). Sebagian besar guru yang diteliti, yakni 43 orang atau $91 \%$ adalah guru berpendidikan sarjana. Hanya 4 orang atau $9 \%$ guru yang berpendidikan magister. Sebaran data pendidikan guru dapat dilihat pada diagram berikut: 


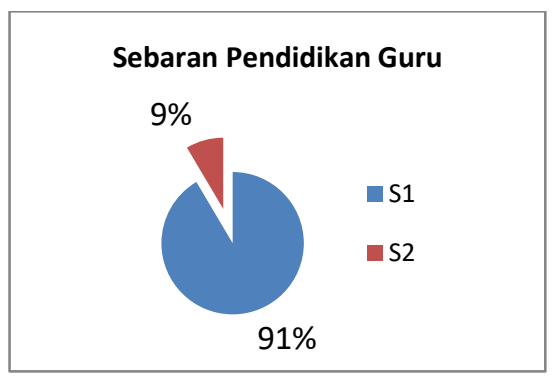

Dari hasil analisis perbedaan dengan uji t menggunakan SPSS, diperoleh hasil analisis sebagai berikut :

Tabel 6: Perbedaan Kinerja berdasarkan Jenjang Pendidikan

\begin{tabular}{lccccc}
\hline & $\begin{array}{l}\text { Levene's Test } \\
\text { for Equality of } \\
\text { Variances }\end{array}$ & $\begin{array}{l}\text { t-test for } \\
\text { Equality } \\
\text { of Means }\end{array}$ & & & \\
\hline & $\mathrm{F}$ & Sig. & $\mathrm{T}$ & $\mathrm{df}$ & $\begin{array}{l}\text { Sig(2 } \\
\text { tailed })\end{array}$ \\
\hline $\begin{array}{l}\text { Equal } \\
\text { variances }\end{array}$ & 0,033 & 0,856 & $-2,232$ & 45 & 0,031 \\
$\begin{array}{l}\text { assumed } \\
\begin{array}{l}\text { Equal } \\
\text { variances not } \\
\text { assumed }\end{array}\end{array}$ & & & & & \\
\hline
\end{tabular}

Dari tabel di atas diperoleh hasil uji homogenitas variansi antar kelompok adalah nilai $F=0,033$ dengan signifikansi 0,856 . Ini bermakna bahwa variansi kedua kelompok yang dibandingkan adalah homogen sehingga layak untuk dibandingkan. Dari tabel di atas juga diperoleh $t_{(45 ; 0,05)}=-2,232$ dengan signifikansi 0,031 atau 3,1\%. Artinya pada taraf signifikansi $5 \%$, disimpulkan ada perbedaan yang signifikans pada kinerja guru dalam melaksanakan pembelajaran daring jika ditinjau dari perbedaan jenjang pendidikan mereka. Secara deskriptif, rata-rata skor kinerja guru berpendidikan sarjana (SI) adalah 83.40, dan ratarata kinerja guru berpendidikan magister (S2) adalah 88.69. Ini bermakna bahwa kinerja guru berpendidikan S2 cenderung lebih tinggi dibandingkan kinerja guru berpendidikan SI dalam melaksanakan pembelajaran daring.

\section{Perbedaan Kinerja Guru ditinjau dari Pangkat Golongan}

Pangkat golongan guru dalam penelitian ini dibedakan menjadi 6 kategori, yakni dari pangkat golongan IIla hingga IVb. Dari hasil penelitian ditemukan bahwa sebagian besar guru atau $61,70 \%$, adalah guru berpangkat IVb. Hanya 3I,9I\% guru yang berpangkat golongan III. Ini mengindikasikan bahwa sebagian besar guru yang diteliti merupakan guru yang sudah senior. Hal itu tergambar pada diagram berikut:

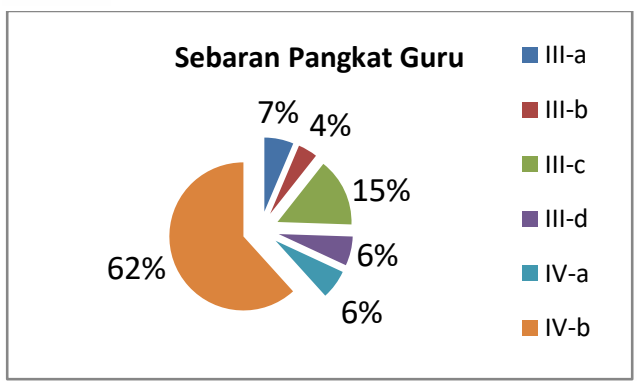

Dari hasil analisis variansi satu jalur menggunakan SPSS, diperoleh hasil uji perbedaan kinerja guru ditinjau dari perbedaan pangkat golongan, sebagaimana tabel ANOVA berikut:

Tabel 7: Anava : Perbedaan Kinerja berdasarkan Pangkat Guru

\begin{tabular}{lrrrrr}
\hline Variance Sources & $\begin{array}{l}\text { Sum of } \\
\text { Squares }\end{array}$ & df & $\begin{array}{l}\text { Mean } \\
\text { Square }\end{array}$ & F & Sig. \\
\hline Between Groups & 266,848 & 5 & 53,370 & 2,879 & 0,026 \\
Within Groups & 759,933 & 41 & 18,535 & & \\
Total & 1026,789 & 46 & & & \\
\hline
\end{tabular}


Dari tabel di atas diperoleh nilai $F_{(5: 41)}=2,879$ dengan signifikansi 0,026. Ini berarti bahwa pada taraf signifikansi 0,05 atau $5 \%$, ada perbedaan kinerja guru dalam melaksanakan pembelajaran daring jika ditinjau dari perbedaan pangkat golongan guru. Dari hasil analisis deskriptif diketahui bahwa rata-rata skor kinerja tertinggi justeru diperoleh guru berpangkat IIId dan IVb. Sedangkan rata-rata skor terendah diperoleh oleh guru berpangkat IIIb.

\section{Pembahasan}

Dari hasil penelitian ditemukan bahwa instrumen supervisi daring yang digunakan kepala sekolah cukup reliabel sehingga secara konsisten dan menghasilkan skor hasil pengukuran yang stabil. Konsistensi hasil pengukuran tersebut juga melambangkan reliabilitas suatu instrumen. Suatu instrumen disebut reliabel jika menghasilkan hasil pengukuran yang cenderung konsisten jika digunakan pada waktu, tempat dan keadaan berbeda, sehingga hasilnya bisa dipercaya (Naga, 1992; Mardapi, 20I2; Mansyur, et.al, 2009). Reliabilitas instrumen ini penting untuk memberi keyakinan tentang akurasi hasil pengukuran dengan menggunakan instrumen tersebut.

Terdapat dua cara yang umumnya digunakan untuk mengetahui reliabilitas instrumen. Cara pertama adalah melalui ujicoba sebelum instrument tersebut digunakan, dan cara kedua adalah melakukan pemeriksaan hasil pengukuran pada saat instrumen tersebut digunakan (Naga, 1992). Jika pemeriksaan dilakukan pada saat sebelum digunakan, maka dilakukan ujicoba instrumen pada situasi dan peserta yang memiliki karakteristik mirip dengan peserta yang menjadi target. Berdasarkan data hasil ujicoba tersebut dapat dilakukan analisis untuk mendapatkan reliabilitas instrumen. Sedangkan jika menggunakan cara yang kedua, maka reliabilitas instrumen dapat ditemukan dengan cara mencari koefisien korelasi antara skor hasil pengukuran dengan skor hasil pengukuran lainnya yang saling unidimensi. Misalkan kita melakukan beberapa jenis tes yang berbeda tetapi secara substansi tes-tes itu mengukur hal yang sama, maka koefisien korelasi suatu tes dengan tes lainnya melambangkan koefisien reliabilitas tes tersebut. Bahkan reliabilitas dapat diketahui dengan penggunaan berulang kali instrumen yang sama, dengan mengabaikan faktor risiko terjadinya carryover effect (Mardapi, 20I2).

Dari hasil penelitian terbukti bahwa koefisien reliabilitas instrumen supervisi daring yang digunakan kepala sekolah masuk kategori tinggi. Reliabilitas itu dilambangkan oleh koefisien $r_{(46 ; 0,05)}=$ $0.71 \mathrm{I}$. Umumnya koefisien reliabilitas di atas 0.70 dianggap sudah cukup baik, cukup tinggi, dan dapat dipercaya. Bahkan pada beberapa cabang ilmu yang metode pengukurannya belum begitu mantap, koefisien reliabilitas 0.50 ke atas sudah dianggap cukup baik (Naga, 1992). Dengan demikian, dapat disimpulkan bahwa instrumen supervisi kepala sekolah yang digunakan secara daring, dapat dipercaya mengukur kinerja guru dalam pembelajaran daring, karena ada konsistensi hasil pengukurannya jika dibandingkan dengan hasil pengukuran luring. Rugaiyah (2016), menyatakan bahwa setiap tahapan supervisi kepala sekolah terhadap kinerja guru, dapat memanfaatkan teknologi informasi.

Dari hasil penelitian ditemukan kinerja guru SMPN-6 Palangka Raya dalam melaksanakan pembelajaran daring berada pada kategori baik dan sangat baik. Skor kinerja yang rendah diperoleh pada komponen pra-observasi, tetapi bobot komponen ini hanya $10 \%$. Bobot ini relatif kecil jika dibandingkan komponen telaah RPP dan observasi terhadap pelaksanaan pembelajaran, memiliki bobot $75 \%$. Hal ini dapat menjelaskan temuan tingginya koefisien korelasi antara skor kinerja guru sebelum pandemi, yang diukur menggunakan instrumen supervisi luring, dengan skor kinerja guru pada pembelajaran daring yang diukur menggunakan instrumen supervisi luring. Korelasi antara kedua skor tersebut cenderung tinggi karena kedua instrumen memiliki kesamaan komponen yang diukur, khususnya pada tahapan penilaian RPP dan supervisi pelaksanaan pembelajaran. Keadaan ini dapat merupakan kritik terhadap pembobotan komponen pada instrumen yang digunakan kepala sekolah serta disarankan penggunaannya oleh Kementerian Pendidikan dan Kebudayaan RI. Pembobotan komponen praobservasi yang memiliki keterkaitan erat dengan penguasaan teknologi informasi, seharusnya diperbesar.

Secara deskriptif diketahui bahwa kelemahan umum yang ditemukan oleh kepala sekolah dalam pembelajaran daring adalah 
kekurangsesuaian antara model dan aplikasi pembelajaran daring dengan karakteristik peserta didik. Kesalahan semacam itu merupakan kesalahan umum. Terjadi. Ada kecenderungan guru hanya menggunakan aplikasi yang dianggapnya umum dan mudah digunakan, seperti aplikasi WhatsApp. Penyebab utamanya karena perubahan cara pembelajaran yang mendadak akibat adanya pandemi, dari luring ke daring, kurang mampu diantisipasi oleh para guru. Keadaan pandemi Covid-19 menyebabkan adanya tuntutan bagi guru dan peserta didik untuk beradaptasi dengan metode pembelajaran yang baru (Rahmawaty, 2020). Adanya kesulitan dalam menggunakan perangkat teknologi informasi merupakan hal yang umum terjadi pada guru-guru, sebagaimana hasil survey Tim Panitia Kerja (Panja) Komisi X DPR-RI (2020), yang menemukan bahwa $67 \%$ guru di Indonesia masih gagap dalam penggunaan teknologi informasi, dan hanya sekitar 3\% guru yang menyatakan tidak ada kendala semacam itu. Vitanova, 2015; Raob, et. al, 2012), menemukan bahwa faktor utama yang berpengaruh dalam pengembangan penguasaan teknologi informasi bagi guru adalah rendahnya pengetahuan dasar tentang teknologi informasi, dan rendahnya keterampilan mengoperasikan komputer. Tambunan (2014) menemukan bahwa kompetensi guru dalam bidang teknologi informasi dipengaruhi kemampuan mereka dalam penggunaan alat-alat komunikasi. Semua faktor tersebut terkait dengan kemampuan adaptasi guru terhadap perkembangan teknologi informasi yang sangat cepat.

Ditinjau dari faktor-faktor yang mempengaruhinya, penelitian ini menemukan bahwa faktor jenjang pendidikan guru merupakan salah satu faktor yang berpengaruh. Ada kecenderungan bahwa guru-guru dengan pendidikan magister memperoleh skor kinerja lebih tinggi dibandingkan guru-guru berpendidikan sarjana. Temuan ini memperkuat pandangan bahwa tingkat pendidikan merupakan faktor yang turut menentukan capaian kinerja guru dalam pembelajaran. Efendi et.al (2019), menemukan bahwa pendidikan tambahan pada guru-guru SLB berpengaruh terhadap kinerja guru bersama-sama dan simultan dengan faktor lain seperti lama bekerja. Marjoon \& Nugroho (2019), menemukan bahwa guru-guru berpendidikan S2 cenderung memperoleh rata-rata skor kinerja lebih tinggi dibandingkan dengan guru-guru berpendidikan lebih rendah. Sedangkan Subaidi (2020), menyarankan perlunya peningkatan jenjang pendidikan guru ke jenjang magister guna meningkatkan kinerja guru.

Selain faktor jenjang pendidikan, faktor yang berpengaruh terhadap kinerja guru dalam pembelajaran daring adalah pangkat golongan guru. Penelitian ini membuktikan bahwa guru-gurun dengan pangkat lebih tinggi cenderung memperoleh skor kinerja lebih tinggi dibandingkan dengan guru berpangkat lebih rendah. Skor kinerja tertinggi diperoleh oleh guru berpangkat IVb dan IIId, dan skor terendah diperoleh oleh guru berpangkat IIIb. Secara teoretis, guru berpangkat lebih tinggi cenderung memiliki pengalaman mengajar lebih banyak, sehingga pemahaman mereka terhadap pelaksanaan pembelajaran secara umum lebih baik. Pengalaman mengajar cenderung meningkatkan kinerja pada kelompok guru tertentu. Syah (2016), menemukan bahwa pengalaman mengajar hanya berpengaruh signifikans terhadap kinerja guru pada guru-guru dengan pengalaman rendah dan menengah, sementara pada guru-guru dengan pengalaman kerja lebih dari 10 tahun ada kecenderungan penurunan kinerja.

Di lain fihak, adanya persyaratan dalam kenaikan pangkat guru, secara bertahap akan menyebabkan guru meningkatkan kompetensinya. Berdasarkan Peraturan Bersama Menteri Pendidikan Nasional dan Kepala Badan Kepegawaian Negara tentang Petunjuk Pelaksanaan jabatan Fungsional Guru dan Angka Kreditnya (2010), disebutkan bahwa unsur yang dinilai dalam kenaikan jabatan fungsional guru terdiri dari unsur utama dan unsure penunjang. Unsur utama terdiri dari pemdidikan, pembelajaran/pembimbingan dan tugas tambahan yang relevan, dan pengembangan keprofesiain berkelanjutan. Sedangkan unsur penunjang terdiri dari memperoleh gelar/ijazah yang tidak sesuai dengan bidang yang diampunya, memperoleh penghargaan/tanda jasa, dan melaksanakan kegiatan yang mendukung tugas guru. Komponen-komponen yang dinilai dalam kenaikan pangkat guru tersebut secara tidak langsung meningkatkan kompetensi dan kinerjanya.

Hasil penelitian juga membuktikan bahwa faktor jenis kelamin guru, bukan merupakan faktor yang menyebabkan perbedaan kinerja guru pada 
pembelajaran daring. Penelitian ini relevan dengan penelitian dari Syah (2016), yang menemukan bahwa jenis kelamin guru tidak berpengaruh terhadap kinerja mereka dalam melaksanakan pembelajaran. Marjoon dan Nugroho (2019) menyimpulkan bahwa tingkat kelulusan guru SMP di Bengkulu dalam Ujian Kompeteni Gurtu (UKG) tidak jauh berbeda antara guru laki-laki dan perempuan. Rachman dan Tjalla (2008), menemukan bahwa tidak ada perbedaan kemampuan pengelolaan kelas antara guru laki-laki dan guru perempuan. Efendi et.al (2019), menemukan bahwa faktor jenis kelamin secara parsial tidak berpengaruh terhadap kinerja guru pada sekolah luarbiasa. Sedangkan penelitian Clifford \& Akpochafo (2015), menemukan bahwa tidak ada perbedaan kompetensi guru laki-laki dan perempuan yang mengajar mata pelajaran ilmu sosial menggunakan metode inquiry di Nigeria. Rachman dan Tjalla (2008), menemukan tidak adanya perbedaan keterampilan pengelolaan kelas antara guru laki-laki dan perempuan. Sementara Nadeem et.al (20II) menyatakan bahwa stigma masyarakat di Punjab yang lebih menghargai guru laki-laki, menyebabkan perbedaan kinerja guru laki-laki dan perempuan. Tetapi pada masyarakat yang lebih demokratis, stigma seperti itu tentu saja tidak terjadi.

Penelitian ini juga menemukan bahwa perbedaan usia guru, bukan merupakan faktor yeng menyebabkan perbedaan kinerja guru. Adanya tuntutan keadaan, menyebabkan para guru yang berusia muda dan tua, dituntut untuk mampu mengembangkan diri sesuai dengan perkembangan teknologi informasi. Temuan ini bertentangan dengan penelitian Ashari (2018) yang menyatakan bahwa pada orang-orang yang usianya sudah cukup tua, terdapat hambatan interpersonal, struktural, dan fungsional, dalam menggunakan perangkat teknologi informasi. Tampaknya hal ini tidak terjadi pada para guru. Adanya tuntutan untuk melaksanakan pembelajaran secara daring, menyebabkan guru berusaha untuk menguasai perangkat teknologi informasi, sekalipun dengan berbagai hambatan dan keterbatasan.

Tidak adanya perbedaan kinerja melaksanakan pembelajaran daring antara guru lakilaki dan perempuan, membuktikan bahwa kemampuan memberi pelajaran secara daring sudah cukup merata antara guru laki-laki dan perempuan, minimal menggunakan aplikasi yang sederhana seperti WhatsApp. Pada kenyataannya, sebagian guru di daerah, lebih akrab menggunakan aplikasi WhatsApp sebagai media pembelajaran daring dibanding aplikasi lain seperti Zoom dan Google-Classroom. Faktor utama yang dipertimbangkan adalah kepraktisan dalam penggunaan, dan kecukupan kouta internet. Guru dan peserta didik akan cenderung menggunakan aplikasi yang dianggap umum dan mudah serta lebih hemat dalam pemakaian kouta.

Selain faktor-faktor di atas, penelitian ini juga menemukan bahwa faktor masa kerja guru tidak berkorelasi positif dengan kinerja mereka. Efendi et.al. (2019) menemukan bahwa faktor lama bekerja secara parsial tidak berpengaruh terhadap kinerja guru, tetapi akan berpengaruh jika faktor tersebut berkombinasi secara simultan dengan faktor pendukung yang lain seperti adanya pendidikan dan pelatihan untuk guru. Jika dikaitkan dengan pangkat golongan guru, maka masa kerja yang lebih lama cenderung dapat ditunjukkan oleh pangkat guru yang lebih tinggi, sehingga seharusnya kinerja guru juga semakin baik. Kontradiksi ini dapat dijelaskan melalui fenomena keterkaitan antar faktor, bahwa faktor masa kerja bukan merupakan faktor tunggal yang berdiri sendiri, tetapi pengaruhnya akan tampak pada saat faktor tersebut berkombinasi dengan faktor lain.

\section{KESIMPULAN}

Dari hasil penelitian disimpulkan bahwa (I). Instrumen yang digunakan kepala sekolah untuk melakukan supervisi secara daring, merupakan instrumen yang reliabel dan bisa dipercaya untuk mengukur kinerja guru dalam pembelajaran daring. Hasil supervisi daring menggunakan instrumen tersebut berkorelasi positif dan signifikans dengan hasil supervisi sebelum pandemi, dengan koefisien korelasi 0,7I. (2). Secara deksriptif, kinerja guru SMPN-6 Palangka Raya dalam pembelajaran daring berada pada kategori baik dan sangat baik, (3). Tidak ada korelasi antara usia guru dengan kinerja guru dalam pembelajaran daring. Koefisien korelasi yang diperoleh sebesar $r_{(46 ; 0,05)}=0,18$ tidak signifikans pada taraf 5\%. (4). Tidak ada korelasi antara masa kerja dengan kinerja guru dalam pembelajaran daring. Koefisien korelasi yang diperoleh sebesar $r_{(46 ; 0,05)}=$ 0,21 , tidak signifikans pada taraf $5 \%$. (5). Jenjang pendidikan guru merupakan faktor yang 
membedakan kinerja guru. Guru dengan pendidikan S2 memperoleh skor kinerja lebih tinggi dibandingkan dengan guru berpendidikan di bawahnya, dengan nilai $t_{(45 ; 0,05)}=-2,23$ yang signifikans pada taraf $5 \%$. (6). Variabel pangkat golongan guru juga merupakan faktor determinan yang menjadi penyebab perbedaan kinerja guru dalam melaksanakan pembelajaran daring. Dari hasil analisis variansi diperoleh $F_{(5 ; 41)}=$ 2,879 yang signifikan pada taraf $5 \%$. Guru berpangkat IIId dan IVb merupakan kelompok guru yang memperoleh rata-rata skor kinerja tinggi. (7). Variabel jenis kelamin bukan merupakan faktor yang menyebabkan perbedaan kinerja guru dalam melaksanakan pembelajaran daring.

Implikasi penelitian ini adalah perlunya perumusan kebijakan pembinaan guru berdasarkan pangkat dan jenjang pendidikan, sehingga kinerja guru dalam pembelajaran daring dapat ditingkatkan.

\section{DAFTAR PUSTAKA}

Ashari, R.G. (20I8). Memahami Hambatan dan Cara Lansia Mempelajari Media Sosial. Jurnal IImu Komunikasi. I5(2). pp. I55-I70.

Bulkani, (2020). Peningkatan Akurasi Tes Daring sebagai Alat Ukur Hasil Belajar Masa Pandemi Covid-19. In, In'am \& Latipun (eds). New Normal, Kajian Multidisiplin, Malang: AMCA \& Psychology Forum. Pp. 89-96.

Clifford, O.E., \& Akpochafo, W.P. (2015). Gender Difference among Social Studies Teachers' Competences in the Use of the Inquiry Method in South-South Nigeria. Journal of Education and Practice. 6(23). pp. 48-52. ISSN: 2222-I735. e-ISSN 2222-288X. www.iiste.org

Efendy, M., Dewantoro, D.A., Pradipta, R.F., \& Ummah, U.S. (2019). Critical Factors in the Performance of Special Education Teachers in Inclusive Schools. International Journal of Innovation, Creativity, and Change. 5(4). Pp. 95-I I2. ISSN 2580-358I: e-ISSN 2580-5037.

DOI: http://dx.doi.org/10.29240/jsmp.v3i2.II59.

Kepmendikbud RI Nomor 7/9/P/2020. Pedoman Pelaksanaan Kurikulum pada Satuan Pendidikan dalam Kondisi Khusus. (Guidelines for Implementing Curriculum in Educational Units in Special Conditions).

Khatoo, H., Azeem, F., \& Akhtar, S.H. (20II). The impact of different factors on teaching competencies at secondary level in Pakistan. Interndiciplinary Journal of Contemporary Research in Business. 3(5). pp. 648-655. ijcrb.webs.com

LPPKSPS: Lembaga Pengembangan dan Pemberdayaan Kepala Sekolah dan Pengawas Sekolah (LPPKSPS) Kementerian Pendidikan dan Kebudayaan. Panduan Kerja Kepala Sekolah di Masa Pandemi Covid-I9. (Principal Work Guidelines during the Covid-19 Pandemic).

Marjoon, M., \& Nugroho, K.U.Z. (2019). The Competence of Teachers Based on Academic Qualification and Gender. Paper presented at: SAMSES20 8 IOP Conf. Series: Journal of Physics: Conf. Series 1318. DOI:10.1088/1742-6596/1318/1/012136

Mansyur, Rasyid, H., \&b Suratno. (2009). Asesmen Pembelajaran di Sekolah. Yogyakarta: Multi Pressindo.

Mardapi, D.(2012). Pengukuran, Penilaian, dan Evaluasi Pendidikan. Yogyakarta: Nuha Medika

Naga, D.S. (1992). Pengantar Teori Skor pada Pengukuran Pendidikan, Jakarta : Gunadarma,

Nadeem, M., Lone, A.H., Maqbool, S., Naz, K., \& Ali, A. (20II). Teacher's Competencies and Factors Affecting the Performance of Female Teachers in Bahawalpur (Southern Punjab) Pakistan. International Journal of Business and Social Science. 2(19). Pp. 217222. www.ijbssnet.com

Niswah, W. (2020). Analisis Supervisi Akademik Kepala Sekolah dan Budaya Sekolah terhadap

Kompetensi Pedagogik Guru SD di Kabupaten Demak. JPAI Jurnal Perempuan dan Anak Indonesia. 2(I). pp. 43-57. ISSN: 2686-289।

Peraturan Bersama Menteri Pendidikan Nasional dan Kepala Badan Kepegawaian Negara Nomor: 03/V/PB/2010 dan Nomor: 14 Tahun 2010. Petunjuk Pelaksanaan Jabatan Fungsional Guru dan Angka Kreditnya. 
(Instructions for Implementation of Functional Teacher Positions and Credit Score).

Rachman, M.P., \& Tjalla, A. (2008). Keterampilan Pengelolaan Kelas Dilihat dari jenis Kelamin dan Kecerdasan Emosi Guru Sekolah Luar Biasa. Jurnal Psikologi. 2(I). pp. I-7.

Raob, I., Al-Qshaibat, H., \& Ong, S.L. (20I2). A Factor Analysis of Teacher Competency in Technology. New Horizons in Education.60(I). Pp. 13-22. Avalaible at: https://files. eric.ed.gov/fulltext/EJ974075.pdf

Rugaiyah (2016). Pengembangan Model Supervisi Klinis Berbasis Informasi dan Teknologi. Cakrawala Pendidikan. XXXV(3). pp. 42I-

Rahmawaty, U.F.R. (2020). Pendidikan di Masa Covid19: White Paper. Jakarta: ISED

Sax, G. (1980). Principles of Educational and Psychological Measurement and Evaluation. San Francisco:Phoenix Publishing Services Inc.

Sekretariat Komisi XI DPR-RI. (2020). Evaluasi Pembelajaran Jarah Jauh. Jakarta:Hetifah Sjaifudian

Sonedi, (2016). Hubungan Kepemimpinan Kepala Sekolah dan Sikap Guru terhadap Pekerjaan dengan Kompetensi Profesional Guru. Anterior Jurnal. 16(I). PP. 14-27. ISSN: |4I2-I395; e-ISSN: 2355-3529

Sonedi, Sholehah, T., \& Dihasbi, (2018). Peran Kepemimpinan Kepala Sekolah dalam Meningkatkan Kinerja Guru. Anterior Jurnal. I8(I). PP. 13-22. ISSN: I4I2-I395; e-ISSN: 2355-3529

Stufflebeam, D.L., \& Shinkfield, A.J. (2007). Evaluation, Theory, Models, \& Applications. San Francisco: Jossey-Bass A Willey Imprint.

Subaidi. (2020). Kepemimpinan Kepala Madrasah Dalam Upaya Meningkatkan Mutu Pendidikan Dan Kinerja Guru Di MAN I Pati. TADBIR Jurnal Studi Manajemen Pendidikan. 4(2). pp. I6I-I74. ISSN: 2580-
358I. e-ISSN: 2580-5037. DOI: http://dx. doi. org//0.29240/jsmp.v4i2.1428

Surat Edaran Kementerian Pendidikan dan Kebudayaan RI Nomor I5 Tahun 2020. Pedoman Penyelenggaraan Belajar dari Rumah dalam Masa Darurat Penyebaran Covid-19. (Guidelines for Organizing Learning from Home in an Emergency during the Covid-19 Spread).

Syah, M.F.J. (2016). Pengalaman, Jenis Kelamin, dan Tingkat Pendidikan: Apakah Mempengaruhi Kinerja Guru Ekonomi/Akuntansi di Kabupaten Semarang, Kota Salatiga, dan Kota Semarang? Presented at : Seminar Nasional Pendidikan (SNP-2016). ISSN: 2503-4855

Tambunan, H. (20I4). Factors Affecting Teachers' Competence in the Field of Information Technology. International Education Studies. 7(I2). pp. 70-75. ISSN: 1913-9020 eISSN: $1913-9039$

Wandi, A. (2018). Analisis Peran Supervisi Kepala Sekolah terhadap Pelaksanaan Tugas Pokok Guru; Studi Tindakan Sekolah di SMPN 2 Situjuah Limo Nagari. JPPI Jurnal Penelitian Pendidikan Indonesia). 4 (I). pp. 7I-77. ISSN : 2477-8524-ISSN. e- ISSN: 2502-8103. DOI https://doi.org/10.29210/02018195

Widoyoko, E.P. (20II). Evaluasi Program Pembelajaran. Yogyakarta: Pustaka Pelajar

Vitanova, V., Pachemska, T.A., Iliev, S., \& Pachemska, S. (20I5). Factors Affecting the Development of ICT Competencies of Teachers in Primary Schools. Procedia Social and Behavioral Sciences. pp. 1087 1094. 